\title{
KEGUNAAN WHATSAPP SEBAGAI MEDIA INFORMASI DAN MEDIA PEMBELAJARAN PADA MAHASISWA ILMU KOMUNIKASI STISIP PERSADA BUNDA
}

\author{
Sartika \\ Program Studi Ilmu Komunikasi STISIP Persada Bunda \\ Email : sartikasari29813@gmail.com
}

\begin{abstract}
Abstrak
Penelitian ini bertujuam untuk mengetahui kegunaan media dalam dunia pembelajaran selain utnuk berkomunikasi dan penyampaian pesan dalam dunia perkuliahan. Maraknya kecanggihan teknologi menempatkan posisi pemakai agar dapat bijak dalam penggunaannya. Sistim pembelajaran ini dapat di tuangkan dalam e-blended learning yang merupakan kajian perpaduan teknologi dan komunikasi yang menarik untuk ditelusuri berdasarkan fungsi media sebagai pembelajaran tersebut. Penggunaan yang tepat dan positif merupakan keputusan yang bijak dalam penggunaan serta pemanfaatan teknologi. Adanya kemajuan bidang teknologi memudahkan dalam pembelajaran, penyaluran pesan melalui media yang tepat dan cepat mulai digemari berbanding terbalik dengan masa terdahulu dimana saat ini semua dapat terakses dengan mudah dan cepat sehingga pemanfaatan yang tepat sangat terasa bermanfaat terutama dalam dunia perkuliahan.
\end{abstract}

Kata Kunci : Whatsapp, Smartphone, Media Pembelajaran

\begin{abstract}
This study aimed to know the usefulness of media in the world of learning other than to communicate and deliver the message in the world of lectures. The rise of technological sophistication puts the user's position in order to be wise in its use. This learning system can be poured in the e-blended learning which is a study of the combination of technology and communication interesting to be traced based on the function of the media as learning. Proper and positive use is a wise decision in the use and use of technology. The existence of technological advancements facilitate the learning, channel distribution through the right media and quickly began favored inversely with the previous period where nowadays all can be accessed easily and quickly so that the proper utilization is very useful especially in the world of lectures.
\end{abstract}

Keywords : Whatsapp, Smartphone, Learning Media

\section{PENDAHULUAN}

Kemajuan teknologi sangatlah mempengaruhi dalam kehidupan kita, terlebih lagi dalam media komunikasi yang memudahkan kita untuk memberikan informasi. Hal ini berkembang sangat cepat dari tahun ke tahun mengalami kemajuan sangat pesat.Salah satunya penggunaan media telepon yang telah mengalami proses peralihan dimana saat ini kecenderungan masyarakat ingin memiliki media yang serba 
efisien dari segi bentuk dan waktu. Maka penggunaan handphone atau telepon genggam adalah solusi dari hasil inovasi terkemuka yang kita temui pada masa sekarang.

Dengan penggunaan handphone ini maka aplikasi serta fitur ikut mengalami peralihan yang tetap menjaga fungsi utama dari media tersebut sebagai sarana komunikasi. Banyak sekali kegunaan handphone ini dalam membantu kita menyebarkan informasi baik untuk pribadi, pekerjaan ataupun untuk keluarga. Salah satu pembahasan yang menarik bagi peneliti untuk membahasnya adalah aplikasi whatsapp. Dimana, aplikasi tersebut selain bisa berbagi informasi tetapi juga bisa mengirim gambar berupa foto-foto bahkan juga dapat merekam suara serta video. Sehingga hal ini merupakan kemudahan dan kelancaran dalam berkomunikasi.

Tentu saja kegunaan ini ditempatkan sesuai dengan fungsinya dan keperluannya tanpa mengurangi nilai fungsi handphone itu sendriri. Tetapi sebaliknya sangat membantu serta mempermudah dalam berkomunikasi. Harga handphone saat ini pun bervariasi mulai dari harga yang terjangkau bagi kalangan ekonomi ke bawah bahkan sampai yang termahal juga ada. Harga menentukan kualitas, merek, serta kelengkapan fitur dan fasilitas tiap handphone berbeda-beda. Dahulu handphone atau telepon genggam merupakan barang mewah karena hanya orang-orang tertentu dapat memilikinya akan tetapi, berbeda dengan masa sekarang handphone merupakan kebutuhan yang tidak bisa lepas sehingga hargapun bukan tolak ukur melainkan pembedaan kualitasnya saja.

Perbedaan kebutuhan berkomunikasi dari masa ke masa mengalami perkembangan, mengingat masyarakat menginginkan komunikasi yang lebih efisien dan menghemat waktu maka terlahirlah smarthphone. Pembedaan dengan handphone terdahulu yakni handphone hanya berfungsi untuk telepon yang lebih menonjolkan sisi kekuatan audio bedahalnya dengan smartphone tetap tidak mengurangi fungsi sebagai media komunikasi hanya saja memiliki lebih banyak kelebihannya, diantaranya selain untuk media audio tetapi juga sebagai kekuatan audio visual. Dengan adanya kamera pada handphone dapat memotret gambar serta record video dan dapat mengirim gambar serta video tersebut kepada orang lain bahkan ke orang banyak sekalipun (group). Kecanggihan ini memiliki dampak yang besar dalam kehidupan masyarakat, bahkan dalam dunia pendidikan sekalipun memiliki fungsi yang cukup besar bagi mahasiswa khususnya.

Bila penempatan kecanggihan teknologi media elektornik seperti smarthphone dapat diposisikan sebagai sarana media yang memiliki kekuatan positif maka memberi kemudahan dalam dunia pembelajaran. Sayangnya, hal ini banyak yang tidak menyadari akan penempatan kecanggihan media elektronik tersebut. Padahal, bila ini direalisasikan dalam dunia pembelajaran maka memudahkan kita untuk menjadikan smartphone sebagai teman berbagi informasi dan pembelajaran. Peneliti tertarik menilai kecanggihan media elektronik dapat membantu dunia pendidikan sebagai sarana penyebaran informasi dan evaluasi belajar. Terutama bidang ilmu komunikasi yang memang tidak lepas dari proses berkomunikasi dimana harus ada komunikator, pesan, serta komunikan yang menjadi syarat sebagai terjadinya komunikasi tentunya melalui perantara media.

Dalam dunia perkuliahan smarthphone memberikan kemudahan dalam pembelajaran seperti memberikan informasi seputaran informasi kampus, materi pem- 
belajaran, komunikasi antara dosen dan mahasiswa baik personal ataupun group, bahkan sebagai evaluasi belajar berupa pengumpulan tugas bersifat file dokumen, audio, bahkan audio visual. Peneliti telah mencoba kegunaan dari aplikasi whatsapp (WA) sangat memudahkan dalam perkuliahan.

Sesuai dengan penjelasan dalam latar belakang pemilihan judul yang telah dikemukakan, maka dapat dirumuskan permasalahannya adalah seberapa besar Kegunaan Whatsapp Smarthphone Sebagai Media Informasi Dan Pembelajaran Pada Mahasiswa Ilmu Komunikasi Semester VI Kelas B1 Di STISIP Persada Bunda. Penelitian ini bertujuan untuk mengetahui Kegunaan Whatsaap Smarthphone Sebagai Media Informasi dan Pembelajaran Pada Mahasiswa Ilmu Komunikasi Semester VI Kelas B1 Di STISIP Persada Bunda.

\section{KERANGKA TEORI}

\section{Whatsapp Smartphone}

Berdasarkan Wikipedia makna dari smartphone belum ada kesepakatan dilihat dari penggunaan bahasa inggris yang memiliki arti ponsel cerdas, yang mempunyai kemampuan dengan pengunaan dan fungsi yang menyerupai komputer. Belum ada standar pabrik yang menentukan arti ponsel cerdas. Bagi beberapa orang, ponsel cerdas merupakan telepon yang bekerja menggunakan seluruh perangkat lunaksistem operasi yang menyediakan hubungan standar dan mendasar bagi pengembang aplikasi. Bagi yang lainnya, ponsel cerdas hanyalah merupakan sebuah telepon yang menyajikan fitur canggih. Dengan kata lain, ponsel cerdas merupakan komputer kecil yang mempunyai kemampuan sebuah telepon. Pertumbuhan permintaan akan alat canggih yang mudah dibawa ke mana-mana membuat kemajuan besar dalam proses, memori, layar dan sistem operasi yang di luar dari jalur telepon genggam sejak beberapa tahun ini.

Belum ada kesepakatan dalam industri ini mengenai apa yang membuat telepon menjadi "pintar", dan pengertian dari ponsel cerdas itu pun berubah mengikuti waktu. Menurut David Wood, Wakil Presiden Eksekutif PT Symbian OS, "Ponsel cerdas dapat dibedakan dengan telepon genggam biasa dengan dua cara fundamental, yakni bagaimana mereka dibuat dan apa yang mereka bisa lakukan." Pengertian lainnya memberikan penekanan perbedaan dari dua faktor ini.

Mempelajari teknologi komunikasi tak lain menggali sejarah perkembangan teknologi itu sendiri. Dengan mempelajari perkembangan teknologi komunikasi ini manusia jadi tahu apa teknologi paling sederhana pernah digunakan untuk membantu berkomunikasi. Secara sederhana teknologi atau bisa disebut dengan alat bantu bisa ditelusuri saat manusia menggunakan media sebagai alat berkomunikasi (Nurudin, $2017: 4$ ).

Dalam jurnal Medium oleh Dasiroh (2017: 2) mengatakan mengikuti perkembangan teknologi digital, kini Handphone tidak hanya digunakan sebagai alat untuk berkomunikasi melalui panggilan dan sms saja, namun lebih dari itu, kemajuan teknologi digital ini telah melahirkan Handphone terbaru yang memiliki multi fungsi yaitu smartphone. 
Telepon seluler generasi ketiga (3G), memiliki teknologi multimedia dan pemancar dengan menggunakan gelombang radio, sehingga telepon seluler memiliki kemampuan mentransmisikan pesan secara real-time. Saat ini seseorang yang ingin menginformasikan pesan kepada orang lain dapat menggunakan telepon selulernya utnuk menyiarkan informasi itu kepada siapa saja yang nomor teleponnya ada dalam selulernya atau dia memasukkan secara manual nomor-nomor tersebut (Bungin, 2008 : 133).

Tingginya penetrasi pengguna telepon seluler ditangkap sebagai fenomena media komunikasi pemasaran yang potensial bagi marketer. Telepon seluler merupakan media komunikasi personal. Kecenderungan saat ini, orang tidak dapat jauh dari telepon selulernya. Telepon seluler merupakan media komunikasi yang berevolusioner dalam sejarah perkembangan teknologi informasi dan komunikasi dunia. Telpon seluler (dengan teknologi GSM) hanya membutuhkan waktu empat tahun untuk mendapatkan 50 juta pengguna (Lindgren dalam Hamid, 2011 : 177).

Tabel 1. Tingkat kekayaan alat-alat komunikasi

\begin{tabular}{|c|c|c|c|}
\hline NO & JENIS KOMUNIKASI & KETERANGAN & KAPAN DIPAKAI \\
\hline \multirow[t]{2}{*}{1.} & \multirow[t]{2}{*}{$\begin{array}{l}\text { Tatap muka (face to } \\
\text { face) }\end{array}$} & $\begin{array}{l}\text { Melibatkan banyak simbol } \\
\text { seperti bahasa, tubuh, dan } \\
\text { ekspresi muka. }\end{array}$ & \multirow[t]{2}{*}{$\begin{array}{l}\text { Terutama bila isinya } \\
\text { menimbulkan keragu- } \\
\text { raguan. }\end{array}$} \\
\hline & & $\begin{array}{l}\text { Umpan balik secara } \\
\text { langsung menimbulkan } \\
\text { pemahaman untuk } \\
\text { pengecekan dan perbaikan } \\
\text { (koreksi). }\end{array}$ & \\
\hline \multirow[t]{3}{*}{2.} & \multirow[t]{3}{*}{$\begin{array}{l}\text { Telepon dan media } \\
\text { personal elektronik } \\
\text { lainnya. }\end{array}$} & \multirow[t]{2}{*}{$\begin{array}{l}\text { Umpan balik dapat dengan } \\
\text { segera diluncurkan, simbol- } \\
\text { simbol masih bisa } \\
\text { ditangkap (terutama nada } \\
\text { suara). }\end{array}$} & $\begin{array}{l}\text { Bila tatap muka tidak } \\
\text { bisa dilakukan dan } \\
\text { perlu segera di } \\
\text { interupsi. }\end{array}$ \\
\hline & & & \multirow{2}{*}{$\begin{array}{l}\text { Bila visual cues tidak } \\
\text { diperlukan. }\end{array}$} \\
\hline & & $\begin{array}{l}\text { Pesan dapat difokuskan } \\
\text { secara personal. }\end{array}$ & \\
\hline \multirow[t]{2}{*}{3.} & \multirow[t]{2}{*}{$\begin{array}{l}\text { Tertulis (surat, } \\
\text { memo, fax) }\end{array}$} & $\begin{array}{l}\text { Simbol-simbol komunikasi } \\
\text { tidak dapat ditangkap. }\end{array}$ & $\begin{array}{l}\text { Bila tidak diperlukan } \\
\text { jawaban segera. }\end{array}$ \\
\hline & & $\begin{array}{l}\text { Umpan balik lamban (tidak } \\
\text { simultan). }\end{array}$ & $\begin{array}{l}\text { Bila visual cues tidak } \\
\text { diperlukan. }\end{array}$ \\
\hline \multirow[t]{2}{*}{4.} & \multirow[t]{2}{*}{$\begin{array}{l}\text { Tertulis (dokumen } \\
\text { resmi, company } \\
\text { profile, brosur, bul- } \\
\text { letin, dll). }\end{array}$} & $\begin{array}{l}\text { Simbol-simbol bersifat } \\
\text { resmi, mewakili organisasi } \\
\text { (tidak personal), makro dan } \\
\text { memerlukan pengendapan } \\
\text { untuk dipahami. }\end{array}$ & \multirow[t]{2}{*}{$\begin{array}{l}\text { Bila perusahaan ingin } \\
\text { menjajaki kerja sama } \\
\text { dan membina } \\
\text { kepercayaan } \\
\text { steakholders. }\end{array}$} \\
\hline & & Dipakai sebagai rujukan & \\
\hline
\end{tabular}


resmi.

Sumber : Richard L.Daft, Organization Theory and Design, 4th Edition dalam Kasali, 2008 : 193.

\section{Media}

Menurut Heinch dalam Rusman, media merupakan alat saluran komunikasi. Media berasal dari bahasa latin dan merupakan bentuk jamak dari kata "medium" yang secara harfiah berarti "perantara" yaitu perantara sumber pesan (a source) dengan penerima pesan (a receiver). Media adalah pengantar pesan dari pengirim ke penerima pesan, dengan demikian media merupakan wahana penyalur informasi belajar atau penyalur pesan. National Education Association (NEA) atau Asosiasi Teknologi dan Komunikasi Pendidikan Amerika mendefinisikan media sebagai segala bentuk dan saluran yang digunakan orang untuk menyalurkan pesan/informasi (Sadiman dkk dalam Rusman, 2011 : 169).

Secara sederhana, istilah media bisa dijelaskan sebagai alat komunikasi sebagaimana definisi yang selama ini diketahui (Laughey dan McQuail dalam Nasrullah, $2017: 3$ ). Terlepas dari cara pandang melihat media dari bentuk dan teknologinya, pengungkapan kata "media" bisa dipahami dengan melihat dari proses komunikasi itu sendiri (Meyrowitz, 1999; Moores, 2005; Williams, 2003 dalam Nasrullah, $2017: 3)$.

Proses terjadinya komunikasi memerlukan tiga hal, yaitu objek, organ, dan medium. Saat menyaksikan sebuah program di televisi, televisi adalah objek dan mata adalah organ. Perantara antara televisi dan mata adalah gambar atau visual. Contoh sederhana ini membuktikan bahwa media merupakan wadah untuk membawa pesan dari proses komunikasi. Beragam kriteria bisa dibuat untuk melihat bagaimana media itu. Ada yang membuat kriteria media berdasarkan teknologinya, seperti media cetak yang menunjukkan bahwa media tersebut dibuat dengan mesin cetak dan media elektornik yang dihasilkan dari perangkat elektronik. Membagi media dalam kriteria-kriteria tertentu akan memudahkan siapa pun untuk melihat media. Hanya pembagian tersebut menempatkan media sekadar alat atau perantara dalam proses distribusi pesan. Padahal, dibalik itu semua media memiliki kekuatan yang juga berkontribusi menciptakan makna dan budaya ( Nasrullah, 2017: 3-4).

\section{Informasi}

Informasi adalah fakta atau apa pun yang dapat digunakan sebagai input dalam menghasilkan informasi. Sedangkan data merupakan bahan mentah, data merupakan input yang setelah diolah berubah bentuknya menjadi output yang disebut informasi. Informasi ialah sejumlah data yang telah diolah melalui pengolahan data dalam rangka menguji tingkat kebenarannya dan ketercapaiannya sesuai dengan kebutuhan. Ada tiga hal penting yang harus diperhatikan dari informasi yaitu : informasi merupakan hasil pengolahan data, memberikan makna, dan berguna atau bermanfaat. Ciri-ciri informasi yang berkualitas ada empat yaitu (Rusman, 2013 : 79-80) : 
1. Akurat, artinya informasi mencerminkan keadaan yang sebenarnya. Pengujiannya biasanya dilakukan oleh beberapa orang yang berbeda, dan apabila hasilnya sama, maka data tersebut dianggap akurat.

2. Tepat waktu, artinya informasi harus tersedia/ada pada saat informasi diperlukan

3. Relevan artinya informasi yang diberikan harus sesuai dengan yang dibutuhkan

4. Lengkap artinya informasi harus diberikan secara utuh tidak setengahsetengah

Informasi dapat disebut pesan, pesan terjadi karena ada penyampaian pesan dan penerima pesan. Terjadi informasi membuat terjalinnya hubungan antara penyampaian pesan dan penerima pesan. Berbicara tentang terjalinnya hubungan antara penyampai pesan dengan penerima pesan dapat disebutkan tingkat hubungan yang terjadi dari kedua pihak (Widjaja, 2008 : 31-32).

\section{Media Pembelajaran}

Belajar merupakan salah satu faktor yang mempengaruhi dan berperan penting dalam pembentukan pribadi dan perilaku individu. Sebagian besar perkembangan individu berlangsung melalui kegiatan belajar. Sedangakan media adalah sebuah alat yang mempunyai fungsi menyampaikan pesan. Dalam pembelajaran, media memegang peranan penting dalam mencapai sebuah tujuan belajar. Hubungan komunikasi antara dosen dan mahasiswa akan lebih efisien jika menggunakan media.

Media pembelajaran adalah alat atau bentuk stimulus yang berfungsi untuk menyampaikan pesan pembelajaran. Bentuk-bentuk stimulus bisa dipergunakan sebagai media di antaranya adalah hubungan atau interaksi manusia, realia, gambar bergerak atau tidak, tulisan, dan suara yang direkam. Kelima bentuk stimulus ini akan membantu peserta didik. Namun demikian, tidaklah mudah mendapatkan kelima bentuk ini dalam satu waktu atau tempat. Media pembelajaran yang baik harus memenuhi beberapa syarat. Media pembelajaran harus meningkatkan motivasi peserta didik. Penggunaan media mempunyai tujuan memberikan motivasi kepada peserta didik. Selain itu media juga harus merangsang peserta didik mengingat apa yang sudah dipelajari selain memberikan rangsangan belajar baru. Media yang baik juga akan mengaktifkan peserta didik dalam memberikan tanggapan, umpan balik dan juga mendorong peserta didik untuk melakukan prkatik-praktik dengan benar (Rusman, 2013 : 61).

Ada lima jenis media yang dapat digunakan dalam pembelajaran, yaitu Rusman. $2013: 62$ ) :

1. Media Visual, adalah media yang hanya dapat dilihat dengan menggunakan indra penglihatan yang terdiri dari atas media yang diproyeksikan dan media yang tidak dapat diproyeksikan yang biasanya berupa gambar diam atau gambar bergerak.

2. Media Audio, yaitu media yang mengandung pesan dalam bentuk auditif yang dapat merangsang pikiran, perasaan, perhatian, dan kemauan para peserta didik untuk mempelajari bahan ajar. Contoh dari media audio ini adalah program kaset suara dan program radio. 
3. Media Audio-Visual, yaitu media yang merupakan kombinasi audio dan visual atau biasa disebut media pandang-dengar. Contoh dari media audio-visual adalah program video /televisi dan program slide suara (sound slide).

4. Kelompok Media Penyaji, media ini sebagaimana diungkapkan Donald T.Tosti dan John R.Ball dikelompokkan ke dalam tujuh jenis, yaitu : (a) kelompok kesatu ; grafis, bahan cetak, dan gambar diam, (b) kelompok kedua ; media proyeksi diam, (c) kelompok ketiga ; media audio, (d) kelompok keempat ; media audio, (e) kelompok kelima ; media gambar hidup/film, (f) kelompok keenam ; media televise, dan (g) kelompok ketujuh ; multimedia.

5. Media objek dan media interaktif berbasis komputer. Media objek merupakan media tiga dimensi yang menyampaikan informasi tidak dalam bentuk penyajian, melainkan melalui ciri fisiknya sendiri, seperti ukurannya, bentuknya, beratnya, susunannya, warnanya, fungsinya, dan sebagainya.

\section{METODE PENELITIAN}

Metode Penelitian adalah prosedur yang dilakukan dalam kegiatan penelitian dengan memperhatikan kaidah ilmiah dan pencapaian tujuan penelitian $(\mathrm{Pu}-$ jileksono, 2015:4) Penelitian ini menggunakan metode kualitatif. Dimana penelitian kualitatif merupakan jenis penelitian yang menghasilkan penemuan-penemuan yang tidak dapat dicapai dengan menggunakan prosedur statistik atau cara kuantitatifikasi lainnya (Ruslan, 2003:202). Adapun subjek penelitian ini merupakan mahasiswa semester VI Kelas B1 sebanyak 8 orang narasumber dengan menggunakan teknik pengumpulan data observasi, wawancara dan dokumentasi.

\section{PEMBAHASAN}

Berdasarkan wawancara dari informan maka dapat ditemukan kegunaan whatsapp smartphone sebagai media informasi dan media pembelajaran. Temuan tersebut dapat disimak melalui hasil wawancara bersama beberapa mahasiswa, yaitu sebagai berikut :

Berdasarkan wawancara yang dilaksanakan maka penggunaan whatsapp smartphone memiliki keterkaitan bukan hanya dalam dunia komunikasi semata tetapi juga berkaitan dengan kecanggihan teknologi dan sistem pembelajaran khususnya dalam dunia perguruan tinggi. Dari hasil wawancara dengan beberapa mahasiswa yang pengguna whatsapp merasakan kegunaannya selain untuk chat atau obrolan dengan sesama teman tetapi juga efektif bila digunakan sebagai sarana pembelajaran sebagai sarana pemberian materi ataupun pengumpulan tugas melalui aplikasi di smartphone mereka.

Bila dilihat dalam teori pembelajaran keterkaitan dengan kemajuan serta kecanggihan dunia komunikasi saat ini adalah teori blended e-learning dimana secara etimologi istilah blended learning terdiri dari dua kata yaitu blended dan learning. Kata blend berarti "campuran, bersama untuk meningkatkan kualitas agar bertambah baik" (Collins Dictionary), atau formula suatu penyelarasan kombinasi atau perpaduan (Oxford English Dictionary) (Heinze and Procter, 2006 : 236). Sedangkan learning memiliki makna umum yakni belajar, dengan demikian sepintas mengandung makna pola pembelajaran yang mengandung unsur pencampuran, atau penggabungan antara satu pola dengan pola lainnya. Apa yang dicampurkan? 
Elenena Mosa (2006) menyampaikan bahwa yang dicampurkan adalah dua unsur utama, yakni pembelajaran di kelas (classroom lesson) dengan online learning (Rusman, 2017 : 242).

\section{Gambar 2 Pure Blended e-Learning (Heinze dalam Rusman, 2017 : 245)}

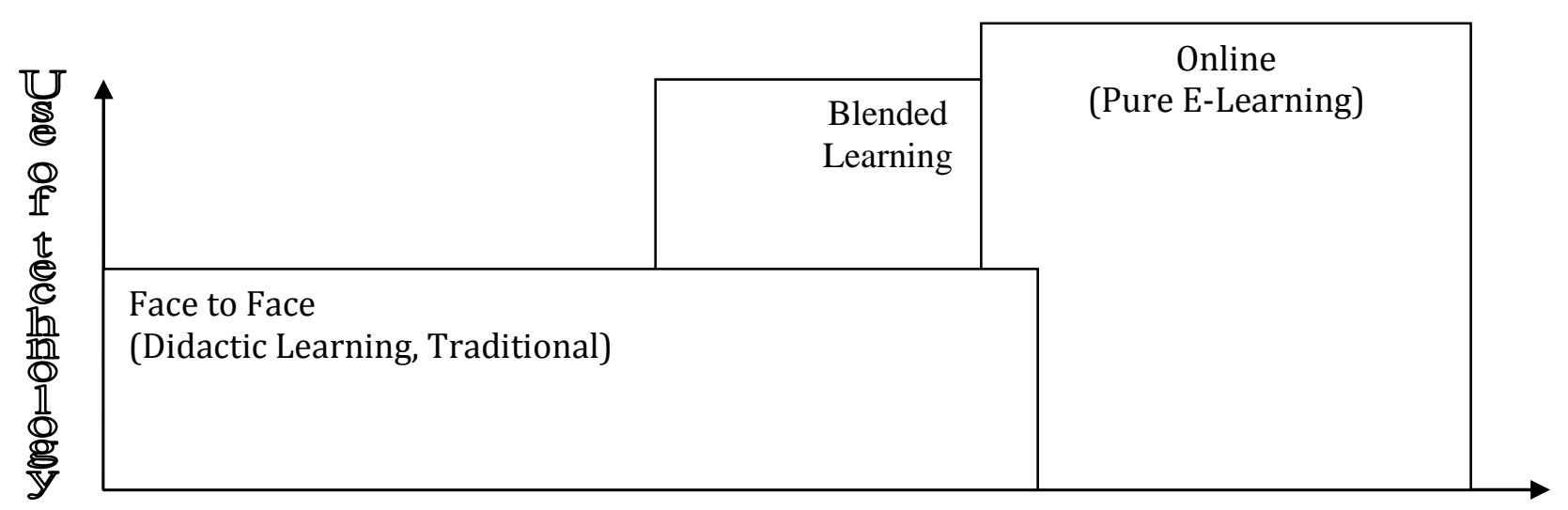

Conception of Blended Learning - adapted from Heinze and Procter (2004)

Menurut Sharpen dalam Rusman mengatakan karakteristik Blended Learning adalah :

1. Ketetapan sumber suplemen untuk program belajar yang berhubungan selama garis tradisional sebagian besar, melalui intsitusional pendukung lingkungan belajar virtual.

2. Transformatif tingkat praktik pembelajaran didukung oleh rancangan pembelajaran sampai mendalam.

3. Pandangan menyeluruh tentang teknologi untuk mendukung pembelajaran.

Jika dikaji secara terminologis maka blended e-learning menekankan pada penggunaan internet seperti pendapat Rosenberg (2001) menekankan bahwa blended e-learning merujuk pada penggunaan teknologi internet untuk mengirimkan serangkaian solusi yang dapat meningkatkan pengetahuan dan keterampilan. Hal ini senada dengan Cambell (2002), Karmaga (2002) yang intinya menekankan penggunaan internet dalam pendidikan sebagai hakikat blended elearning. Lebih lanjut Onno W. Purbo (2002) menjelaskan bahwa istilah "e" atau singkatan dari elektronik dalam blended e-learning digunakan sebagai istilah untuk segala teknologi yang digunakan untuk mendukung usaha-usaha pengajaran lewat teknologi elektronik internet (Rusman, 2017 : 249-250).

Bila dilihat dari perspektif komunikasi, pembelajaran serta teknologi saling berkaitan diantara ketiga hal tersebut sehingga dapat kita simpulkan secara keseluruhan bahwa metode pembelajaran dapat digunakan sebagai penyalur 
informasi mengenai perkuliahan dengan perantara kecanggihan teknologi sebagai medianya. Hal ini dapat kita simak melalui hasil dari wawancara bersama pengguna whatsapp yang telah lama menggunakan aplikasi ini di smartphone mereka seperti yang diutarakan oleh Janice yang diwawancarai pada tanggal 5 April 2017 yang mengatakan bahwa adanya whatsapp sangat membantu kehidupan dari segi waktu, efisiensi, serta ekonomis karena pemakaiannya yang sangat praktis seperti mengirim pesan yang langsung terhubung melalui sistem internet dari smartphone langsung tersampaikan pesan yang diberikan. Bila ada gambar yang akan dikirim sangat memungkinkan karena kualitas gambar yang bagus dari aplikasi ini dapat dengan mudah diterima oleh orang yang dituju. Bahkan video juga sangat mudah untuk mengirimnya hingga dokumen seperti file word berupa tugas dari dosen tidak membuang waktu harus kirim melalui email tetapi cukup dari handphone sudah bisa memungkinkan pengiriman tersebut langsung diterima oleh dosen yang bersangkutan.

Hal ini memudahkan kinerja dosen selain memberikan materi pengajaran dikelas tetapi untuk evaluasi belajar mengajar maka dibutuhkannya pemberian tugas dari dosen dengan memanfaatkan kecanggihan teknologi seperti whatsapp sangat memudahkan proses belajar mengajar. Tidak hanya itu dalam aplikasi ini juga tidak merepotkan sipenerima pesan harus menyimpan gambar yang dikirim oleh si komunikatornya dengan sistem otomatis langsung tersimpan seperti yang diungkapkan oleh Regina yang diwawancarai pada tanggal 12 April 2017 mengatakan bahwa memakai whatsapp sangat memudahkan karena disaat menerima pesan berbentuk gambar tidak perlu harus save gambar tersebut tetapi secara langsung sudah tersimpan dengan sendirinya fitur ini yang tidak dimiliki oleh aplikasi lainnya.

Hal yang sama juga diungkapkan oleh Randi yang diwawancarai pada tanggal 17 April 2017 yang mengatakan bahwa bila dibandingkan dengan fitur lain harus membuka dulu isi pesannya berupa gambar tetapi berbeda dengan whatsapp tanpa perlu kita membuka filenya secara langsung sudah tersimpan dengan sendirinya. Ini yang tidak dimiliki fitur lain seperti bbm (blackberry messenger).

Kemudahan yang lain juga dirasakan oleh Anisa yang diwawancarai pada tanggal 3 Mei 2017 manyatakan bila ingin berkomunikasi dengan seseorang kita hanya butuh nomor handphone saja bila tersimpan nomornya, maka akan ada dalam aplikasi whatsapp tanpa perlu ID yang lain bedahalnya dengan BBM yang meminta invite terlebih dahulu dengan memasukan nomor pin BB nya sehingga baru bisa berkomunikasi dengan orang tersebut itu pun juga harus dengan diterima terlebih dahulu pertemanannya bila ditolak maka tidak bisa untuk berkomunikasi dengan orang yang dituju.

Menurut Janice yang diwawancarai pada tanggal 5 April 2017 selain untuk mengirim gambar (visual), suara (audio), video (audio visual), tetapi whatsapp juga berperan utnuk video call berupa panggilan dengan terlihat gambar gerak (audio visual)/video sehingga orang yang dihubungi dapt terlihat bentuk wajahnya seakan berbicara secara face to face karena terlihat langsung respon oleh si penerima, hal ini digunakan terlebih lagi untuk menjalin hubungan komunikasi dengan kerabat yang jauh tidak bisa bertemu secara langsung karena jarak yang cukup jauh 
biasanya sangat sering digunakan berkomunikasi dengan keluarga yang jauh dari kita.

Dalam metode pembelajaran yang dirasakan dapat berkomunikasi dengan dosen yang bersangkutan seperti yang diutarakan oleh Glory wawancara pada tanggal 26 April 2017 menceritakan terkadang untuk informasi mengenai perkuliahan dosen juga suka berkomunikasi melalui whatsapp termasuk memberitahukan bila dosen hadir terlambat karena sesuatu hal atau menanyakan hal penting yang berkaitan dengan dunia perkuliahan.

Hal serupa juga dirasakan oleh Noferliman yang diwawancarai pada tanggal 10 Mei 2017 mengatakan bahwa terkadang dalam perkuliahan bila ada dosen yang memberikan tugas dan kurang memahaminya bisa menjadi bahan diskusi dengan teman tentang tugas tersebut secara tidak langsung memudahkan untuk media komunikasi dengan topik belajar atau diskusi materi kuliah. Dari kemudahan komunikasi ini sangat membantu dalam belajar karena kurangnya pemahaman materi kuliah dapat di diskusikan dengan teman atau bertanya langsung dengan dosen yang bersangkutan bila memungkinkan.

Untuk perspektif komunikasinya sendiri sesuai dengan proses komunikasi yang mana adanya komunikator, pesan dan komunikan seperti yang dikatakan oleh Alfisyahrin yang diwawancarai pada tanggal 24 Mei 2017 mengatakan bahwa proses komunikasi terjadi bila menggunakan whatsapp ada komunikatornya, pesan yang disampaikan, dan komunikannya melalui perantara media berupa elektronik yaitu smartphone yang langsung terhubung dengan internet sehingga komunikasi dapat berjalan lancar.

Tidak hanya dalam dunia pembelajaran bahkan sudah merambah dalam dunia kerja seperti yang diterangkan oleh Mardianingsih yang diwawancarai pada tanggal 19 April 2017 yang menerangkan bahwa dalam dunia kerja saat ini segala informasi berkaitan dengan pekerjaan diberitakan melalui whatsapp bila tidak ada membuka whatsapp maka akan ketinggalan informasi seputaran pekerjaan mengingat dalam pekerjaan diadakannya bentuk grup memberikan informasi serta diskusi seputaran dunia kerja.

Dalam penelitian ini hasil yang diperoleh adalah sebagai berikut :

1. Penggunaan media komunikasi sesuai pada penempatan sebagaimana mestinya melalui aplikasi whatsapp smartphone sesama penggunanya terutama dalam ruang lingkup perguruan tinggi.

2. Metode pembelajaran juga dapat ditemukan melalui aplikasi whatsapp sebagai mediator penunjang fasilitas dalam penyampaian materi maupun tugas yang diberikan kepada mahasiswa.

3. Mempermudah proses berkomunikasi disertai kelengkapan pendukung seperti obrolan, pengiriman gambar, audio/suara, audio visual/video, dokumen seperti file bentuk Microsoft word atau pdf, serta video call.

4. Mengupayakan memanfaatkan kecanggihan teknologi pada aktifitas yang lebih positif seperti untuk fasilitas dalam perkuliahan. 
Menyadarkan baik mahasiswa ataupun dosen sebagai sarana baru sistem pembelajaran memakai elektronik berbasis kecanggihan teknologi yang langsung terkoneksi dengan internet.

\section{KESIMPULAN}

Berdasarkan hasil penelitian maka dapat disimpulkan bahwa kegunaan whatsapp smartphone sebagai media informasi sangat berperan dalam memberikan serta menyebarkan informasi ke orang lain. Serta dalam perkuliahan kegunaan whatsapp smartphone sebagai sarana berkomunikasi baik pemeberian materi mata kuliah yang berupa penjelasan bila dalam kelas mahasiswa kurang memahami materi saat dalam proses belajar mengajar dalam kelas. Tidak hanya itu kegunaaan whatsapp juga untuk penyempurna sarana pengiriman tugas dari dosen ke mahasiswa karena dari segi waktu sangat efisien tidak terlalu lama tugas perkuliahan dapat terkirim dengan mudah dan segera diterima oleh dosen yang bersangkutan.

Berdasarkan penelitian yang dilakukan maka hal-hal yang dapat diberi saran menyangkut perihal tepat guna dalam pemakaian aplikasi whatsapp ini. Diharapkan sebagai pengguna lebih cerdas dalam penempatan pemakaiannya agar tidak memakai serta memanfaatkan kecanggihan teknologi utnuk hal-hal yang kurang bermanfaat. Ibarat pisau bermata dua, kegunaan suatu kecanggihan teknologi dapat posisi yang benar bila pengguna menempatkan sesuai dengan fungsinya tetapi akan berdampak negatif bila pengguna kurang memahami dalam penempatannya.

\section{DAFTAR PUSTAKA}

Bungin, Burhan. 2008. Sosiologi Komunikasi : Teori Paradigma, dan DiskursusTeknologi Komunikasi Di Masyarakat, Kencana : Jakarta.

Hamid, Farid dkk. 2011. Ilmu Komunikasi Sekarang dan Tantangan Masa Depan. Kencana : Jakarta.

Kasali, Rhenald. 2005. Manajemen Public Relations Konsep dan Aplikasinya Di Indonesia. Pustaka Grtafiti : Jakarta.

Nasrullah, Rulli. 2012. Komunikasi Antarbudaya Di Era Budaya Cyber. Kencana : Jakarta.

2017. Media Sosial Perspektif Komunikasi, Budaya, dan Sosioteknologi, Simbiosa Rekatama : Bandung.

Nurudin. 2017. Perklembangan Teknologi Komunikasi. Rajawali Pers : Jakarta.

Pujileksono, Sugeng. (2015). Metode Penelitian Komunikasi. Malang: In-trans Publishing.

Ruslan, Rosady. (2003). Metode Penelitian Public Relations dan Komunikasi. Jakarta: PT. Raja Grafindo.

Rusman, dkk. 2013. Pembelajaran Berbasis Teknologi informasi dan Komunikasi. Rajagrafindo Persada : Jakarta. 
Volume 6 Nomor 2

ISSN: 2303-0194

E-ISNN: 2615-1308

Widjaja. 2008. Komunikasi \& Hubungan Masyarakat,. Bumi Aksara : Jakarta.

Jumiatmoko STIT Madina Sragen. Wahana Akademika, Vol.3 No.1, April 2016. WhatsApp Mesengger Dalam Tinjauan Manfaat dan Adab.

Iwayan S.A. Mukti, Arie S.M. Lumeta, Brave A. Sugiarso. Teknik Informatika Universitas Sam Ratulangi Vol. 7 No. 1, Januari 2016. Rancang Bangun Aplikasi Pembelajaran Untuk Anak Umur 6-9 Tahun Berbasis Android.

Daisaroh,Umi, Miswatun, Siti, Ilahi, Yudi Fasrah, Nurjannah.2017. Fenomena Nomophobia di Kalangan Mahasiswa (Studi Deskriptif Kualitatif Mahasiswa Universitas Riau) Medium Jurnal Ilmiah Fakultas Ilmu Komunikasi Vol 6 No. 